CARNETS DE Carnets de géographes

GÉOGRAPHES.

$3 \mid 2011$

Les géographies des enfants et des jeunes

\title{
Louise Chawla (2002), Growing up in an Urbanizing
}

World

Paris, Londres, UNESCO / Earthscan

Anupama Nallari

(2) OpenEdition

Journals

Electronic version

URL: http://journals.openedition.org/cdg/2389

DOI: $10.4000 /$ cdg.2389

ISSN: 2107-7266

Publisher

UMR 245 - CESSMA

Electronic reference

Anupama Nallari, « Louise Chawla (2002), Growing up in an Urbanizing World », Carnets de géographes [Online], 3 | 2011, Online since 01 December 2011, connection on 24 September 2020. URL : http:// journals.openedition.org/cdg/2389; DOI : https://doi.org/10.4000/cdg.2389

This text was automatically generated on 24 September 2020 .

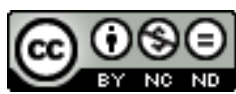

La revue Carnets de géographes est mise à disposition selon les termes de la Licence Creative Commons Attribution - Pas d'Utilisation Commerciale - Pas de Modification 4.0 International. 


\title{
Louise Chawla (2002), Growing up in an Urbanizing World
}

\author{
Paris, Londres, UNESCO / Earthscan
}

Anupama Nallari

\section{REFERENCES}

Louise Chawla (ed.) Growing up in an Urbanizing World, 2002, Paris, Londres, UNESCO Publishing / Earthscan

1 As the world continues to urbanize, Growing up in an Urbanizing World still remains an extremely relevant text almost a decade after it was first published. Recent reports from the United Nations' Population Division (2009) show that 3.4bn or half of the world's population now reside in urban areas and $50 \%$ of these populations are made up of children. A majority of these children live at the intersections of poverty, rapid urban change, lack of basic services, traditional values, and global trends. The authors in this book embark on engaging children in deeply participatory processes to understand their complex relationships to the places where they live and to improve urban conditions by bringing children's voices to the adult centric arena of urban planning and development.

2 Kevin Lynch, a visionary urban planner, started a research project called 'Growing Up in Cities' in the 1970's with the support of UNESCO to better understand how cities contribute towards the overall development of children. This project took place in four working class neighborhoods in Poland, Argentina, Australia, and Mexico and revealed how urban issues such as increased traffic, urban crime, social stigma, and lack of adequate play resources - issues that are still very relevant today - affect children's daily lives. The project stood out for its simplicity in design and ability to adapt to a variety of sites. While Lynch expected his research to gain popularity and be replicated in many parts of the world - specifically low-income areas in developing countries - it was not to be. Almost 20 years later, in a world more aware of children's rights and 
environmental sustainability, Louise Chawla, the editor of this text, sought to revive the Growing Up in Cities project (GUIC). With support from the UNESCO MOST (Management of Social Transformations) program and a host of local funding agencies she was able to revive the research project in eight cities from both the global North and South (namely: Warsaw, Poland; Buenos Aires, Argentina; Northampton, United Kingdom; Melbourne, Australia; Trondheim, Norway; Oakland; USA; Johannesburg, South Africa; and Bangalore, India). While the aim was to conduct follow up research in all of the sites from the first phase of the project, it was possible only in two (Warsaw, Poland, and Melbourne, Australia) due to logistical and funding difficulties. A key addition to the second phase of GUIC was to involve children in participatory local planning, design and policy- towards realizing some of the changes the young people envisioned for their neighborhoods.

This book is a summary of the revival of the Growing Up in Cities project. The book is laid out in ten chapters. In the first chapter, editor Louise Chawla, provides a platform for the chapters to come by discussing the key theoretical and methodological frameworks that inform this study, she describes how this study differs from the earlier initiative, and states the overall goals for the project. Chapters two through nine are country reports from principal researchers, where the research process, methodology, and findings are described in detail for each project. In the last chapter, Chawla summarizes the overall project and draws out key comparative findings that will help guide urban planning and policy professionals in creating urban environments better suited for children. The appendix has research guidelines, methods and interview questions followed by the research teams in all countries.

Apart from the objective descriptions of each location's physical and social features at the beginning of each country report, and common research goals, little else remains constant across the various projects. Each study varies in research design, geographical scale of site (from a small apartment complex in Oakland, California to neighborhoods spanning 614 Acres as in Hunsbury, Northampton), number of participants (from as few as 23 in Johannesburg to 181 in Northampton), and methods used. An important finding in spite of this diversity is that '..there is a remarkable consensus about the qualities that create places where children and adolescents can thrive, versus conditions that cause them to feel alienated and marginalized.' ( $p$ 17)

5 For example, research from Buenos Aires, Argentina and Bangalore, India (chapters 2 \& 6) revealed that despite difficult living conditions, socio-cultural factors such as local culture, rooted traditions, and children's inclusiveness in community life kept children happy and satisfied with their neighborhood. Robin Moore and Nilda Cosco found that children living in Boca Braccas an inner-city low-income neighborhood in Buenos Aires thrived in the cultural richness of the local environment. Even in the face of insecure tenure, poverty, and crime these children maintained a strong sense of self-identity and took active part in community life. Similarly, in India, David Driskell and Kanchan Bannerjee found that children living in Sathyanagar, a peripheral slum in Bangalore, took pride in their modest homes and traditional roots. These young people in spite of shouldering large responsibilities at home and contending for basic services like water on a daily basis were for the most part 'happy, content, and resilient'. Robust social networks, a culture of democracy, access to natural diversity, and land tenure were some of the factors that the researchers found attributed towards these children's positive outlook. Children from both these research sites felt safe to roam around their 
neighborhood and nearby areas. These two chapters also emphasize how children living in low-income neighborhoods may lack material comforts but enjoy diverse social and cultural affordances and a high degree of spatial freedom which their richer counterparts lack living in high-rise apartments and gated communities with tightly packed daily schedules.

6 Children from Semilong and Hunsbury in Northampton, and Braybrook, Melbourne (chapters 3 \& 4) expressed alienation from their locality as they felt that their neighborhoods lacked age appropriate play provision and spaces where they could sit and talk with their friends.

7 Girls in particular expressed fear in navigating through certain areas that were frequented by thieves, drunks and drug addicts. The local police and adults in both these research sites saw groups of boys 'hanging out' on the street as a threat to the social fabric of the community and therefore worked towards removing children from the public sphere of the street. As a result of these exclusionary practices, both boys and girls were seen to be retreating to the private domain of the home and away from the public sphere of the street. Boys took to watching television and playing video games, while girls took care of siblings, chatted with friends, and watched television.

The research projects reported in this book are rich with children's voices, illustrations, photographs, and maps from across the globe that tell the story of what it means to be a child growing up in a poor or relatively low-income neighborhood. The chapter by Jill Swart-Kruger on children living in a squatter camp called Canaansland in Johannesburg is particularly powerful in transporting the reader into the midst of these children's lives. This chapter not only reveals the physical, social, and cultural experiences of these children but also the unpredictable nature of life in squatter communities representative of millions of other young people across the globe. SwartKruger describes the utter shock and hopelessness felt by families and children when they are served eviction notices and ordered to relocate to a larger camp $40 \mathrm{~km}$ from the city. This act depleted people's material and social capital and moreover traumatized children with a deep-seated powerlessness of insecurity. In the new settlement, which was already home to over thousand families, the new arrivals struggled to make ends meet and had to contend for meager resources with hostile residents. The research team reached out to the families of Canaansland with as much material resources, time, and energy they could garner. They also rekindled participatory process to establish a play and study center (planned for the Cannansland area) in the new settlement that enabled the Canaansland people to form bonds with existing residents and helped alleviate some of the hostility between them.

This text also emphasizes that the global North and South cannot be grouped as separate entities when it comes to children's experience of their urban environments. Take for example children's mobility, the chapters (6 \& 7) from India and Norway show that children from both these studies displayed relative confidence and freedom traversing through their neighborhoods by themselves or in the company of siblings or friends. Whereas children from the USA, England, Australia, and South Africa felt less safe exploring their neighborhoods due to a variety of reasons such as social stigma, fear of crime, and lack of adequate play opportunities.

10 As the reader progresses from one country report to the next it becomes increasingly clear that having children's participation instated in urban planning and development is a daunting task. Most research teams expressed deep frustration while working with 
government bodies to bring about a systemic inclusion of children's voices in urban development processes and decisions. Municipal governments were tokenistic and manipulative in their acceptance of children's participation and the GUIC projects. They frequently tried to co-opt the projects for their own publicity, assured research teams that they were well aware of children's needs - which seldom coincided with what children said they needed. Municipal officials primarily encouraged processes where they could get political mileage and while in paper mandated children's participation in urban planning seldom put it into practice. Where research teams were able to implement systemic change the results were rewarding for all parties involved showing that meaningful participation can go a long way.

All the country reports in this book are a standing testament to the fact that children, when given an opportunity, are able to express their views about matters that concern them and provide meaningful suggestions for making their living environments a better place for all age groups. Through participatory processes research teams were able to open up some alternative geographies for these young participants.

This book complements other vital texts in the arena of children and the urban environment such as Cities for Children (Bartlett et.al, 1999), Child and the City (Christensen and O'Brien, 2003), and Cool Places (Skelton and Valentine, 1998). This text along with its companion volume David Driskell's Creating Better Cities with Children and Youth are valuable resources for people in urban planning, community development, and urban governance, as well as for those who advocate for children like national and international NGOs and grassroots organizations.

\section{BIBLIOGRAPHY}

BARTLETT S., HART R., SATTERTHWAITE D., DE LA BARRA X., and MISSAIR A. (1999), Cities for Children: Children's Rights, Poverty and Urban Management, London, Earthscan.

CHRISTENSEN P. and O'BRIEN M. (Eds.) (2003), Children in the City: Home, Neighbourhood and Community, London, Routledge.

DRISKELL D. (2002), Creating Better Cities with Children and Youth: A Manual for Participation, Paris, London, UNESCO Publishing/Earthscan

SKELTON T. and VALENTINE G. (Eds.) (1998), Cool Places: Geographies of Youth Cultures, London, Routledge.

United Nations Population Division (2009), World Urbanization Prospects: The 2009 Revision.

INDEX

Subjects: Carnets de lectures 


\section{AUTHORS}

\section{ANUPAMA NALLARI}

City University of New York

Psychologie Environnementale

anupama_nallari[at]yahoo.com 